Anton Tkachenko*, Anatolii Onishchenko, Yevgen Posokhov, Alexander Roshal, Valeriy Myasoedov and Oksana Nakonechna

\title{
Changes in cell membranes of white blood cells treated with a common food additive E407a
}

\section{YYGIN BIR GIDA KATKI MADDESI OLAN E407a ILE MUAMELE EDILEN BEYAZ KAN HÜCRELERININ HÜCRE MEMBRANLARINDAKI DEĞişiKLiKLER}

https://doi.org/10.1515/tjb-2020-0129

Received April 4, 2020; accepted February 10, 2021;

published online March 12, 2021

\section{Abstract}

Objectives: To estimate the state of phospholipid bilayer of rats WBCs exposed to a common food additive E407a, which is used as a thickener and emulsifier, during $4 \mathrm{~h}$ using a fluorescent probe - ortho-hydroxy derivative of 2,5-diaryl-1,3-oxazole.

*Corresponding author: Anton Tkachenko, PhD, MD, Associate Professor, Research Institute of Experimental and Clinical Medicine, Kharkiv National Medical University, Trinklera St. 6,61022 Kharkiv, Ukraine; and Department of Biochemistry, Kharkiv National Medical University, Kharkiv, Ukraine, Phone: +380 5010945 54,

E-mail: antontkachenk0555@gmail.com. https://orcid.org/00000002-1029-1636

Anatolii Onishchenko, Research Institute of Experimental and Clinical Medicine, Kharkiv National Medical University, Kharkiv, Ukraine; and Department of Biochemistry, Kharkiv National Medical University, Kharkiv, Ukraine

Yevgen Posokhov, Research Institute of Experimental and Clinical Medicine, Kharkiv National Medical University, Kharkiv, Ukraine; and Educational and Scientific Institute of Chemical Technology and Engineering, The National Technical University "Kharkiv Polytechnic Institute", Kharkiv, Ukraine

Alexander Roshal, Institute of Chemistry, V. N. Karazin Kharkiv National University, Kharkiv, Ukraine

Valeriy Myasoedov, Department of Medical Biology, Kharkiv National Medical University, Kharkiv, Ukraine

Oksana Nakonechna, Department of Biochemistry, Kharkiv National Medical University, Kharkiv, Ukraine
Materials and methods: Steady-state fluorescence spectroscopy: a study by the environment-sensitive fluorescent probe - 2-(2'-hydroxy-phenyl)-5-phenyl-1,3-oxazole (probe 010).

Results: Changes are detected in the spectra of the fluorescent probe bound to rat WBCs treated with the solutions of E407a of various concentrations in comparison with the corresponding spectra of the probe incubated with the untreated leukocytes. The decrease in polarity and protondonor ability is observed in the lipid membranes of leukocytes in the region, where the probe locates.

Conclusions: Our findings suggest a higher dehydration of leukocyte membranes of rats treated with a common food additive E407a at high concentrations and, thus, indicate that exposure to high doses of E407a leads to the increase in the lipid order (i.e. to decrease in fluidity) of the membranes of rat WBCs.

Keywords: carrageenan; cell membrane; fluorescent probe; leukocytes; processed Eucheuma seaweed.

\section{Öz}

Amaç: Koyulaştırıcı ve emülgatör olarak kullanılan yaygın bir gıda katkı maddesi E407a'ya maruz kalan sıçanların fosfolipid çift tabakasının durumunu 4 saat boyunca bir floresan prob - 2,5 diaril-1,3-oksazol orto-hidroksi türevi kullanarak tahmin etmek.

Gereç ve yöntem: Kararlı durum floresan spektroskopisi: çevreye duyarlı floresan probu - 2-(2'-hidroksi-fenil)-5-fenil1,3-oksazol (prob 010) tarafından yapılan bir çalışma.

Bulgular: Muamele edilmemiş lökositler ile inkübe edilmiş probun karşılık gelen spektrumlarına kıyasla çeşitli 
konsantrasyonlarda E407a çözeltileri ile muamele edilmiş sıçan WBC'lerine bağlanan floresan probun spektrumlarında değişiklikler tespit edilir. Probun bulunduğu bölgedeki lökositlerin lipid membranlarında polaritede ve proton verici kabiliyetinde azalma gözlenir.

Sonuçlar: Bulgularımız, yüksek konsantrasyonlarda yaygın bir gıda katkı maddesi E407a ile tedavi edilen sıçanların lökosit membranlarında daha yüksek bir dehidrasyon olduğunu göstermektedir ve bu nedenle, yüksek dozlarda E407a'ya maruz kalmanın lipid düzeninde artışa (yani akışkanlıkta azalmaya) yol açtığını göstermektedir. sıçan WBC'lerinin zarları.

Anahtar Kelimeler: İrlanda yosunu; işlenmiş Eucheuma yosunu; floresan prob; hücre zarı; lökositler.

\section{Introduction}

Carrageenans (CGNs) are currently believed to be the most widespread marine polysaccharides used in food industry [1]. Their unique rheological properties allow CGNs to occupy a niche in the market of food additives, where they are known as E407 (refined CGN) and E407a (semi-refined CGN or processed Eucheuma seaweed, PES). Both E407 and E407a are approved for use within the borders of the European Union by the European Food Safety Organization and are used as thickening and stabilizing agents for the production of processed meat, dairy products, and confectionary. CGNs are extracted from marine red algae, in which they may constitute up to $75 \%$ of dry weight, and structurally consist of sulfated D-galactose derivatives linked with glycosidic bonds [2].

It is worth noting that application of CGNs is not limited to the food markets only. There is some evidence that CGNs show antiviral, anticancer and immunomodulatory effects and many researches have been undertaken to explore their potential as a drug [3-5]. Furthermore, these biomacromolecules can be used for drug delivery and as prebiotics [6, 7].

Despite its approval for use as a component of food by international authorities such as the Food and Drug Administration and EFSA, CGNs have been claimed to be unsafe for human consumptions [8-12]. In recent years, evidence from animal studies and cell culture experiments allows suggesting that CGN promotes intestinal inflammation and upregulates cytokines in intestinal epithelial cells $[8,12]$. It is believed that CGNs are able to aggravate the already existing pathogen-induced inflammation in the gut [10]. Such hypothesis is consistent with the findings on the ability of CGN to enhance lipopolysaccharide-induced secretion of pro-inflammatory cytokines $[13,14]$. However, McKim et al. claim that data on pro-inflammatory effects of CGNs and their contribution to the development of intestinal inflammation is misinterpreted due to the confusion in terms [15]. In particular, poligeenan and degraded CGN, which are products of hydrolysis of food-grade CGN with lower molecular weights, are referred to as CGNs. Their ability to induce inflammation in the gut of laboratory animals has been widely recognized and both poligeenan and degraded CGN are not approved for being used in food industry. However, the digestive fate of CGN is still under debate and more studies are required to clarify whether low-molecularweight fragments can be produced from food-grade CGN molecules as a result of their acidic hydrolysis.

CGNs have been demonstrated to induce the generation of reactive oxygen species (ROS) by various types of cells, including neutrophils [16-18]. ROS-mediated lipid peroxidation affects cell membrane structure. It has been reported that lipid peroxidation increases the membrane viscosity and, thus, reduces the fluidity of cell membranes [19, 20]. Such changes may be detected using fluorescent probes.

The aim of our research was to assess the state of rat WBC cell membranes exposed to the solutions of PES (1, 2, and 5\%) during $4 \mathrm{~h}$ using the fluorescent probe 010 (2(2'-hydroxy-phenyl)-5-phenyl-1,3-oxazole).

\section{Methods}

\section{Study design}

The study was conducted using eight female adult WAG rats weighing 160-190 g. The rats were housed in two cages (four rats in each cage) in standard laboratory conditions at $24 \pm 2{ }^{\circ} \mathrm{C}$ two weeks prior to the experiment. The access to food and drinking water was free. The animals were anesthetized and sacrificed with the subsequent collection of blood into sterile EDTA VACUTAINER tubes. Two milliliters of blood collected in the VACUTAINER tubes was taken and equally distributed between four capped polysterene test tubes for each out of eight samples. Thus, four portions ( $500 \mu$ in each) of non-coagulated blood were prepared from each sample. Then $100 \mu \mathrm{L}$ of phosphate buffered saline (PBS, pH 7.4; BD, USA), 1, 2 and 5\% solutions of E407a, respectively, were added to each of those volumes of blood. Blood samples treated with PBS and E407a solutions were incubated for $4 \mathrm{~h}$. It has been reported that the content of CGN in dairy products varies from 0.005 to $0.5 \%$ of weight [8]. Thus, for our study, we selected the concentration of CGNs within this range.

All procedures were approved by the local Bioethics Committee. The care and used of laboratory animals was performed in accordance with the EU Directive 2010/63/EU on the protection of animals used for scientific purposes, based on the Council of Europe Convention for the Protection of Vertebrate Animals used for Experimental and other Scientific Purposes (ETS123). 


\section{PES and its solutions}

Solutions with various concentrations (1, 2, and 5\%) of food grade $\mathrm{k}$-carrageenan-containing PES were prepared in advance $24 \mathrm{~h}$ prior to the experiment. PES has been reported to contain up to $15 \%$ of algal cellulose and traces of formaldehyde [21]. To prepare the solution of food additive PES, solid E407a were added to PBS (BD, USA). Then $100 \mu \mathrm{L}$ of the corresponding stock solutions were added to $500 \mu \mathrm{L}$ of blood. The solutions were gently vortexed prior to their addition to blood samples.

\section{Lyse/wash protocol}

WBC suspensions were obtained from the blood samples treated with PBS and solutions of PES following the lyse/wash procedure (Becton Dickinson Technical Support Protocol, 2002). According to this protocol, $100 \mu \mathrm{L}$ of each sample was added to new $12 \times 75 \mathrm{~mm}$ capped polysterene test tubes. To lyse RBCs, $2 \mathrm{~mL}$ of $1 \times$ FACSLyse solution (Becton Dickinson, San Jose, USA) was added. The solutions were vortexed. Incubation of the solutions obtained as a result lasted for $15 \mathrm{~min}$ at $24^{\circ} \mathrm{C}$ with no exposure to light. It was followed by centrifugation at $500 \mathrm{~g}$ for $5 \mathrm{~min}$. The supernatant was discarded. Then $2 \mathrm{~mL}$ of PBS was added with the centrifugation at $500 \mathrm{~g}$ for $5 \mathrm{~min}$. The supernatant was discarded again. The suspensions were immediately used for the incubation with the fluorescent probe 010 .

\section{Characteristics of the fluorescent probe}

The cells were fluorescently labeled by the same procedure: an aliquot of the probe stock solution in acetonitrile was added to the WBC suspensions to achieve a final probe concentration $\sim 5 \cdot 10^{-6} \mathrm{~mol} / \mathrm{L}$.
Lipid-to-probe molar ratio was 200:1. Before fluorescence measurements, the cell suspensions were incubated with the probes at room temperature for $1 \mathrm{~h}$. The fluorescence spectra were measured on a fluorometer "Hitachi F850" in the range of 350-630 nm, with an increment of $2 \mathrm{~nm}$. The excitation wavelength was $330 \mathrm{~nm}$. The excitation and emission slits were $5 \mathrm{~nm}$.

In this study, we used the fluorescent probe 010, since its fluorescence parameters depend upon the polarity and proton-donor ability of the microenvironment [22-25].

Probe 010 locates (Figure 1): in the area of glycerol backbones of phospholipids, closer to the center of the lipid bilayer; in the area of carbonyl groups of phospholipids and in the area of hydrocarbon chains of phospholipids, near the carbonyl groups of phospholipids [22, 23].

When the probe 010 is in the excited state, the excited state proton transfer reaction occurs [22-25] (Figure 2). In result of this reaction, the phototautomer form $\left(T^{\star}\right)$ is formed. The photoproduct is fluorescent in significantly longer wavelengths in comparison with the initial (or so-called "normal”) form $\left(\mathrm{N}^{\star}\right)$ [22-25].

The presence of two-band fluorescence enables us to conduct ratiometric measurement, i.e. to use the ratio of the phototautomer form and the initial form fluorescence intensities $\left(I_{\mathrm{T}^{\star}} / I_{\mathrm{N}^{\star}}\right)$ as a parameter for estimation of the physical and chemical properties of the microenvironment.

\section{Statistical analysis}

Statistical comparisons were carried out with the help of GraphPad Prism 5.0 (GraphPad software, USA). We evaluated the differences between four independent groups using non-parametric analysis of variance (Kruskal-Wallis test). Numerical values are presented as medians and interquartile ranges. $\mathrm{p}$ values below 0.05 were considered to be statistically significant.
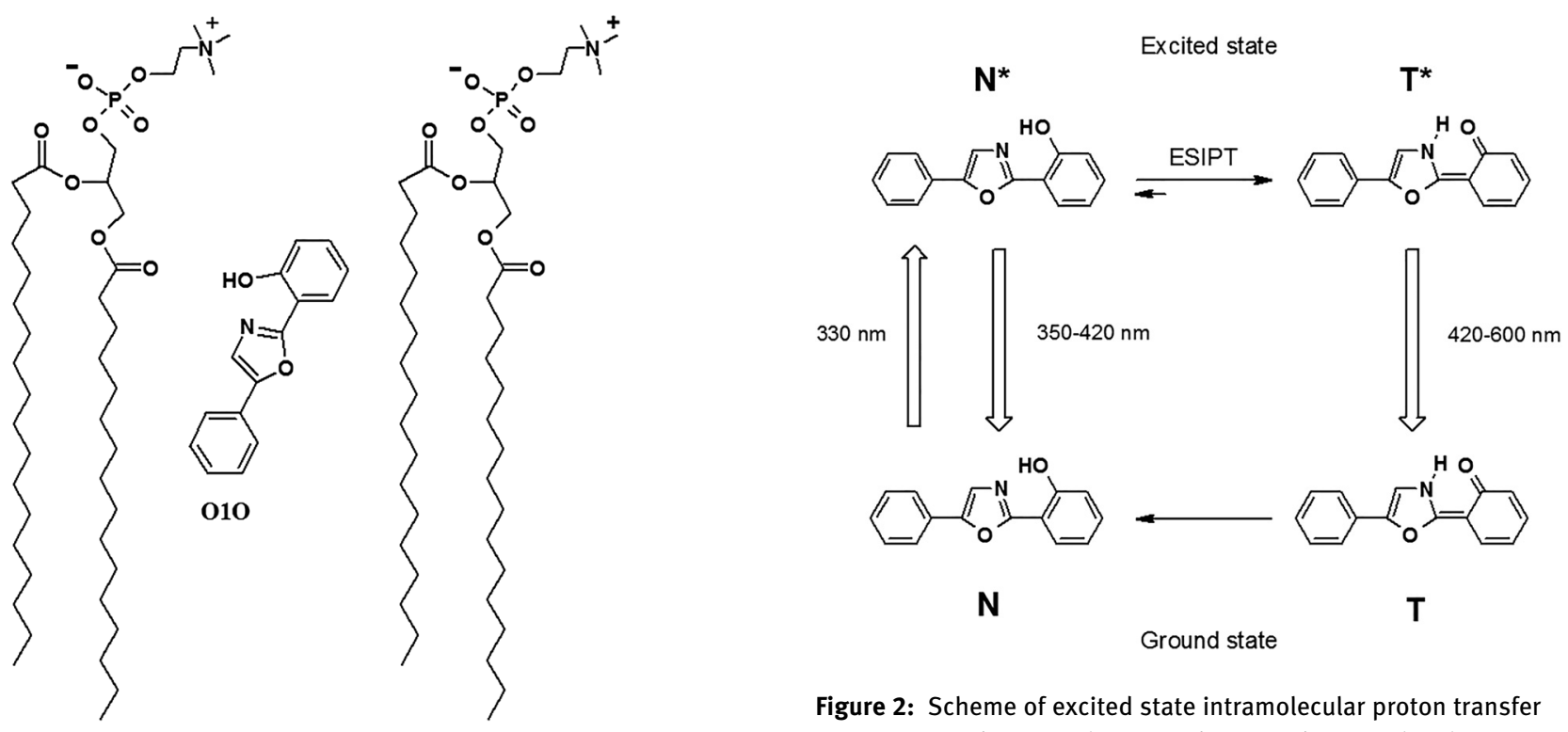

Figure 2: Scheme of excited state intramolecular proton transfer reaction in probe 010 . The upwards arrow denotes the electronic excitation and the downwards arrow designates the fluorescence. Corresponding maximum of absorption and the ranges of emission are shown in nanometers (modified from Posokhov and Kyrychenko [23]).
Figure 1: Localization and orientation of fluorescent probe 010 in phospholipid membranes. Two molecules of phosphatidylcholine from the outer leaflet are shown to denote the localization of the probe (adapted from Posokhov and Kyrychenko [23]). 


\section{Results}

Outcomes of fluorescence measurements are summarized in Table 1 and Figure 3. The incubation of rat leukocytes with the common food additive E407a affected the state of cell membranes.

To assess the effects mentioned above, the ratio of the fluorescence intensities of phototautomer and normal forms $\left(I_{\mathrm{T}^{\star}} / I_{\mathrm{N}^{\star}}\right)$ of probe 010 in the leukocyte membranes of rodents was analyzed (Table 1 ). The $I_{T^{\star}} / I_{\mathrm{N}^{\star}}$ ratios of probe O1O for WBC suspensions treated with 1 and $2 \%$ solutions of E407a during $4 \mathrm{~h}$ were higher compared with the control samples. However, in both cases, the difference was found to be statistically insignificant ( $p>0.05$ ). Thus, at lower concentrations no changes were revealed. Meanwhile, the exposure of the leukocytes to $5 \%$ E407a solution resulted in a statistically significant increase in the $I_{\mathrm{T}^{\star}} / I_{\mathrm{N}^{\star}}$ ratio ( $p<0.05)$ (Table 1). Thus, we can observe that the state of phospholipid bilayer is affected at high concentrations of the food-grade CGN-containing food additive.

In this study, the observed increase in the fluorescence intensity ratio $\left(I_{\mathrm{T}^{\star}} / I_{\mathrm{N}^{\star}}\right)$ points to both a decrease in polarity $[22,24,25]$ and a reduction of proton-donor ability of the environment of probe 010 [23] in the membranes of rat leukocytes exposed to the 5\% solution of E407a.

It is important to note that in fluorescence spectrum of probe 010 in WBCs incubated with the 5\% E407a solution (Figure 3), short-wavelength shift $(\sim 22 \mathrm{~nm})$ of the fluorescence maximum of the normal form $\left(\mathrm{N}^{\star}\right)$ and longwavelength shift ( $\sim 9 \mathrm{~nm})$ of the fluorescence maximum of the phototautomer $\left(\mathrm{T}^{\star}\right)$ were observed in comparison with the corresponding spectrum for the control samples. Such changes were considered another demonstration that the polarity of the probe microenvironment decreased [22, 24, 25].

To sum up, only high concentrations of E407a, in contrast to its lower concentrations, could promote

Table 1: The ratio of the fluorescence intensities of the phototautomer and normal forms $\left(I_{T^{\star}} / I_{\mathrm{N}^{\star}}\right)$ of probe 010 in the leukocyte membranes of rats (Me [IQR]).

\begin{tabular}{lrr}
\hline Groups & $\begin{array}{l}\text { Concentrations } \\
\text { of E407a in the } \\
\text { solutions used }\end{array}$ & $I_{\mathrm{T}^{*}} / I_{\mathbf{N}^{*}}\left(I_{\mathbf{4 8 0}} / I_{\mathbf{3 8 5}}\right)$ \\
\hline $\begin{array}{l}\text { WBCs untreated } \\
\text { with E407a } \\
\text { (control group) }\end{array}$ & $0 \%$ & $2.6[2.4 ; 2.8]$ \\
Leukocytes treated & & \\
with E407a & $1 \%$ & $2.8[2.3 ; 3.4] \mathrm{p}>0.05$ \\
& $2 \%$ & $2.9[2.7 ; 3.0] \mathrm{p}>0.05$ \\
& $5 \%$ & $7.2[6.8 ; 7.7] \mathrm{p}<0.05$ \\
\hline
\end{tabular}

Differences were considered statistically significant at $p<0.05$.

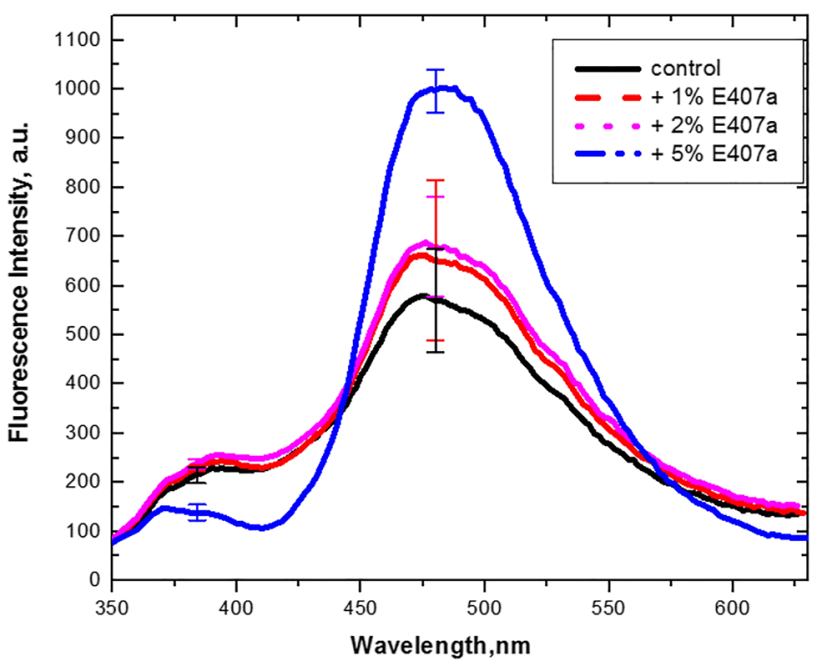

Figure 3: Average fluorescence spectra of probe 010 in leukocyte suspensions: (a) the control group of rats (black solid line), (b) WBCs exposed to the $1 \%$ solution of E407a (red dashed line), (c) leukocytes treated with the $2 \%$ E407a solution (magenta dotted line); (d) WBCs incubated with the $5 \%$ E407a solution (blue dash-dot line). Standard deviation is shown on the fluorescence bands.

modifications, which were detected by measuring the fluorescence of probe 010, in the structure of phospholipid bilayer of leukocytes incubated with this food additive.

\section{Discussion}

The abovementioned decrease in the polarity and the proton-donor ability of the microenvironment of probe $\mathrm{O} 1 \mathrm{O}$ is indicative of dehydration [26-30] of the membrane. The discussed dehydration, in its turn, suggests the increase of the membrane lipid order [26-30].

Thus, our results provide evidence that exposure of WBCs to high doses of E407a leads to the increase in the lipid order of the leukocyte membranes.

According to the Fluid Mosaic Model, cell membranes are composed of a phospholipid bilayer, in which molecules of phospholipids are oriented in two opposite directions. The fluid state of cell membrane is of crucial importance for cellular viability, since it provides the permeability of phospholipid bilayer [31]. It is important to note that the fluid features of cell membranes is maintained by polyunsaturated fatty acids (PUFAs), while long-chain saturated fatty acids, on the contrary, diminish the fluidity and, therefore, increase the viscosity, which is in a reciprocal relationship with fluidity [32].

It has been demonstrated that when phospholipid tails in cell membranes are oxidized, they become shorter [33], which affects the fluidity of membranes, as well as their 
thickness. It is worth mentioning that ROS can initially oxidize the head groups of phospholipids and only after that fatty acid tails undergo oxidation [34]. Thus, the fluorescent probe selected by us is suitable for the detection of changes in the lipid membranes caused by ROS due to its location. We can hypothesize that the reduction of leukocyte membrane fluidity identified by the probe can be attributed to lipid peroxidation $[19,20]$.

The cell membrane is of huge importance in most cellular processes. Its functions are not restricted to being a physical barrier. The cell membrane also provides communication with extracellular environment. In addition, protein receptors and transporters that are crucial for determining the cell response to various challenges are embedded in the membrane. Thus, membrane packing seriously affects the features of cellular responses in normal and pathological conditions [35]. Membrane fluidity is a physical property that reflects how molecules move in the phospholipid layers. It may depend on the fatty acid composition, cholesterol percentage, and cholesterol/ phospholipid ratio [36].

There is accumulating evidence that lipid order alterations in leukocytes affect their functions and, hence, features of the immune response. It has been reported that changes in membrane lipid order and fluidity reduce leukocyte motility and chemotaxis [37]. Furthermore, lipid order alterations in cell membranes of neutrophils influence their extravasation [38]. Thus, CGN-associated changes in leukocyte membranes found in this study may have negative impact on leukocyte effectiveness and modify the immune response. However, more experimental data have to be collected to confirm this hypothesis.

It is worth mentioning that structurally CGNs are reminiscent of glycosaminoglycans (GAGs). Both of them are sulfated polyanionic heteropolysaccharides [39]. Sahoo and Schwille (2013) stated that GAGs are capable of diminishing the diffusion rate of lipid in the outer leaflet of phospholipid bilayer, which resulted in an increased microviscosity, higher lipid order, and, thus, reduced hydration [40]. It is believed that the electrostatic interactions between positively charged phospholipid heads and negatively charged sulfated groups of CGNs underlie the changes in lipid dynamics. Our findings are consistent with those that occur in cell membranes under the influence of GAGs. Thus, the increased viscosity and lipid order of membranes in WBCs exposed to high concentrations of PES found in this study may be attributed to a direct interaction of negatively charged CGN characterized by the high level of sulfation and positively charged surface of outer leaflet.

\section{Conclusion}

The obtained results point to dehydration of membranes of rat WBCs treated with high doses of common food additive E407a and, thus, indicate that the exposure to high concentrations of E407a leads to the increase in the lipid order of the leukocyte membranes.

Acknowledgments: We would like to show our gratitude to all colleagues contributed to this research.

Research funding: None declared.

Author contributions: All authors have accepted responsibility for the entire content of this manuscript and approved its submission.

Competing interests: Authors declare no conflict of interest.

Ethical approval: The study was performed in accordance with the EU Directive 2010/63/EU on the protection of animals used for scientific purposes, based on the Council of Europe Convention for the Protection of Vertebrate Animals used for Experimental and other Scientific Purposes (ETS123).

Çıkar Çatışması: Yazarlar çıkar çatışması bildirmezler.

\section{References}

1. Campbell R, Hotchkiss S. Carrageenan industry market overview. Tropical seaweed farming trends. Problems and opportunities. Nova Science Publishers, Inc.; 2017:193-205 pp.

2. Vera J, Castro J, Gonzalez A, Moenne A. Seaweed polysaccharides and derived oligosaccharides stimulate defense responses and protection against pathogens in plants. Mar Drugs 2011;9: 2514-25.

3. Besednova NN, Zvyagintseva TN, Kuznetsova TA, Makarenkova ID, Smolina TP, Fedyanina LN, et al. Marine algae metabolites as promising therapeutics for the prevention and treatment of HIV/ AIDS. Metabolites 2019;9:87.

4. Pangestuti R, Kim SK. Biological activities of carrageenan. Adv Food Nutr Res 2014;72:113-24.

5. Wang W, Wang SX, Guan HS. The antiviral activities and mechanisms of marine polysaccharides: an overview. Mar Drugs 2012;10:2795-816.

6. Cherry P, Yadav S, Strain CR, Allsopp PJ, McSorley EM, Ross RP, et al. Prebiotics from seaweeds: an ocean of opportunity? Mar Drugs 2019;17:327.

7. Li L, Ni R, Shao Y, Mao S. Carrageenan and its applications in drug delivery. Carbohydr Polym 2014;103:1-11.

8. David S, Shani Levi C, Fahoum L, Ungar Y, Meyron-Holtz EG, Shpigelman A, et al. Revisiting the carrageenan controversy: do we really understand the digestive fate and safety of carrageenan in our foods? Food Funct 2018;9:1344-52. 
9. Bixler HJ. The carrageenan controversy. J Appl Phycol 2017;29: 2201-7.

10. Martino JV, Van Limbergen J, Cahill LE. The role of carrageenan and carboxymethylcellulose in the development of intestinal inflammation. Front Pediatr 2017;5:96.

11. Necas J, Bartosikova L. Carrageenan: a review. Vet Med 2013;58: 187-205.

12. Tobacman JK. Review of harmful gastrointestinal effects of carrageenan in animal experiments. Environ Health Perspect 2001;109:983-94.

13. Wu W, Zhen Z, Niu T, Zhu X, Gao Y, Yan J, et al. k-Carrageenan enhances lipopolysaccharide-induced interleukin- 8 secretion by stimulating the Bcl10-NF-KB pathway in HT-29 cells and aggravates $C$. freundii-induced inflammation in mice. Mediat Inflamm 2017;2017:8634865.

14. Ogata M, Matsui T, Kita T, Shigematsu A. Carrageenan primes leukocytes to enhance lipopolysaccharide-induced tumor necrosis factor alpha production. Infect Immun 1999;67:3284-9.

15. McKim JM, Willoughby JA Sr., Blakemore WR, Weiner ML. Clarifying the confusion between poligeenan, degraded carrageenan, and carrageenan: a review of the chemistry, nomenclature, and in vivo toxicology by the oral route. Crit Rev Food Sci Nutr 2018;14:1-20.

16. Barth CR, Funchal GA, Luft C, de Oliveira JR, Porto BN, Donadio $M V$. Carrageenan-induced inflammation promotes ROS generation and neutrophil extracellular trap formation in a mouse model of peritonitis. Eur J Immunol 2016;46:964-70.

17. Borthakur A, Bhattacharyya S, Anbazhagan AN, Kumar A, Dudeja PK, Tobacman JK. Prolongation of carrageenaninduced inflammation in human colonic epithelial cells by activation of an NFKB-BCL10 loop. Biochim Biophys Acta 2012; 1822:1300-7.

18. Bhattacharyya S, Dudeja PK, Tobacman JK. Carrageenan-induced NFkappaB activation depends on distinct pathways mediated by reactive oxygen species and $\mathrm{Hsp} 27$ or by Bcl10. Biochim Biophys Acta 2008;1780:973-82.

19. Reiter RJ, Tan D-X, Galano A. Melatonin reduces lipid peroxidation and membrane viscosity. Front Physiol 2014;5:377.

20. Tsuda K. Oxidative stress and membrane fluidity of red blood cells in hypertensive and normotensive men: an electron spin resonance investigation. Int Heart J 2010;51:121-4.

21. Cohen SM, Ito N. A critical review of the toxicological effects of carrageenan and processed Eucheuma seaweed on the gastrointestinal tract. Crit Rev Toxicol 2002;32:413-44.

22. Posokhov YO, Kyrychenko A, Korniyenko Y. Derivatives of 2,5-diaryl-1,3-oxazole and 2,5-diaryl-1,3,4-oxadiazole as environment-sensitive fluorescent probes for studies of biological membranes. In: Geddes CD, editor. Reviews in Fluorescence 2017. Cham: Springer Nature Switzerland AG; 2018 : 199-230 pp. [Chapter 9].

23. Posokhov Y, Kyrychenko A. Location of fluorescent probes (2-hydroxy derivatives of 2,5-diaryl-1,3-oxazole) in lipid membrane studied by fluorescence spectroscopy and molecular dynamics simulation. Biophys Chem 2018;235:9-18.

24. Doroshenko AO, Posokhov EA, Verezubova AA, Ptyagina LM, Skripkina VT, Shershukov VM. Radiationless deactivation of excited phototautomer form and molecular structure of ESIPT-compounds. Photochem Photobiol Sci 2002;1: 92-9.

25. Doroshenko AO, Posokhov EA, Shershukov VM, Mitina VG, Ponomarev OA. Intramolecular proton-transfer reaction in an excited state in a series of ortho-hydroxy derivatives of 2,5-diaryloxazole. High Energy Chem 1997;31:388-94.

26. Noethig-Laslo V, Šentjurc M Transmembrane polarity profile of lipid membranes. Advances in planar lipid bilayers and liposomes. Amsterdam: Academic Press, Elsevier; 2006, vol 5:365-415 pp. [Chapter 13].

27. Binder H, Gawrisch K. Effect of unsaturated lipid chains on dimensions, molecular order and hydration of membranes. J Phys Chem B 2001;105:12378-90.

28. Bartucci R, Guzzi R, Marsh D, Sportelli L. Intramembrane polarity by electron spin echo spectroscopy of labeled lipids. Biophys J 2003;84:1025-30.

29. Kurad D, Jeschke G, Marsh D. Lipid membrane polarity profiles by high-field EPR. Biophys J 2003;85:1025-33.

30. Ho C, Slater SJ, Stubbs CD. Hydration and order in lipid bilayers. Biochemistry 1995;34:6188-95.

31. Catalá Á. Lipid peroxidation modifies the assembly of biological membranes “The Lipid Whisker Model”. Front Physiol 2015;5: 520.

32. Maulucci G, Cohen O, Daniel B, Sansone A, Petropoulou PI, Filou $\mathrm{S}$, et al. Fatty acid-related modulations of membrane fluidity in cells: detection and implications. Free Radic Res 2016;50: S40-50.

33. Wong-Ekkabut J, Xu Z, Triampo W, Tang IM, Tieleman DP, Monticelli L. Effect of lipid peroxidation on the properties of lipid bilayers: a molecular dynamics study. Biophys J 2007;93: 4225-36.

34. Yusupov M, Wende K, Kupsch S, Neyts EC, Reuter S, Bogaerts A. Effect of head group and lipid tail oxidation in the cell membrane revealed through integrated simulations and experiments. Sci Rep 2017;7:5761.

35. Poggi P, Mirabella R, Neri S, Assirelli E, Dolzani P, Mariani E, et al. Membrane fatty acid heterogeneity of leukocyte classes is altered during in vitro cultivation but can be restored with ad-hoc lipid supplementation. Lipids Health Dis 2015;14:165.

36. Scott RB, Collins JM, Hunt PA. Alzheimer's disease and down syndrome: leukocyte membrane fluidity alterations. Mech Ageing Dev 1994;75:1-10.

37. Kantar A, Oggiano N, Giorgi PL, Fiorini R. Membrane fluidity of polymorphonuclear leukocytes from children with primary ciliary dyskinesia. Pediatr Res 1993;34:725-8.

38. Seely AJ, Pascual JL, Christou NV. Science review: cell membrane expression (connectivity) regulates neutrophil delivery, function and clearance. Crit Care 2003;7:291-307.

39. Yang B, Bhattacharyya S, Linhardt R, Tobacman J. Exposure to common food additive carrageenan leads to reduced sulfatase activity and increase in sulfated glycosaminoglycans in human epithelial cells. Biochimie 2012;94:1309-16.

40. Sahoo H, Schwille P. Influence of glycosaminoglycans on lipid dynamics in supported phospholipid bilayers. Soft Matter 2013; 9:3859-65. 